\title{
Climate Change and Water Dynamics in Rural Uganda
}

\author{
Laura McKinney ${ }^{1, *}$ and Devin C. Wright ${ }^{2}$ (D) \\ 1 Department of Sociology, Environmental Studies Program, Tulane University, New Orleans, LA 70118, USA \\ 2 Department of Sociology, City, Culture, and Community Program, Tulane University, New Orleans, LA 70118, \\ USA; dwright10@tulane.edu \\ * Correspondence: lauramc@tulane.edu
}

check for updates

Citation: McKinney, L.; Wright, D.C. Climate Change and Water Dynamics in Rural Uganda. Sustainability 2021, 13, 8322. https://doi.org/10.3390/ su13158322

Academic Editors: Mohammad Valipour and Marc A. Rosen

Received: 7 June 2021

Accepted: 17 July 2021

Published: 26 July 2021

Publisher's Note: MDPI stays neutral with regard to jurisdictional claims in published maps and institutional affiliations.

Copyright: (c) 2021 by the authors. Licensee MDPI, Basel, Switzerland. This article is an open access article distributed under the terms and conditions of the Creative Commons Attribution (CC BY) license (https:/ / creativecommons.org/licenses/by/ $4.0 /)$.

\begin{abstract}
The purpose of this case study is to examine the effects of climate change on agricultural life in rural Uganda. Based on primary data, the authors examine major themes related to climate change and disasters as conveyed by individuals in a small agricultural region in Eastern Uganda. Specifically, we focus on the effects of living in constant threat of flooding and landslides. Results show that water is a major source of loss for most people, ranging from crop loss to contaminated water. Findings also point to the chronic nature of dealing with water issues, as opposed to acute. Further, our results indicate that disasters are a great equalizer among affected populations, with only neighbors to depend on in the aftermath.
\end{abstract}

Keywords: climate change; water crises; Uganda; community sustainability; landslides

\section{Introduction}

The purpose of this project is to advance an interdisciplinary analysis of climate change and water dynamics based on data gathered from a small agricultural village in Eastern Uganda. The overarching questions guiding this research are: How do global citizens experience water in their daily lives? How do communities confront the perilous challenges posed by water, be it too much or too little? What are the cascading impacts on communities arising from the intersection of climate change and water dynamics?

Global climate change introduces new challenges for coping with environmental fluctuations. It is imperative to integrate research from different geographic locations and diverse disciplines as we seek solutions to the complex problems posed by this looming crisis. The project responds to this demand by applying the coupled human and natural systems (CHANS) framework [1-3] to analyze the intersection of localized water issues with climate change. The results underscore the challenges emerging from changing water fortunes globally [4].

The project uses a case study methodology and draws on rich ethnographic, qualitative fieldwork and historical/archival data gathered in the Bududa district in Eastern Uganda, where heavy rains come earlier and harder due to climate change, triggering landslides with incalculable loss and injury to the community [5-8]. The Bududa district in Eastern Uganda represents a particularly poignant case of climate change vulnerability given its ecology, remote location, overall impoverishment, poor infrastructure, lack of access to healthcare, and inadequate sanitation [9-11]. Moreover, the widespread reliance on agriculture as a livelihood strategy makes Bududa households especially susceptible to devastation wrought by climate-related crises and extreme weather events (e.g., droughts, floods, landslides) that threaten their ability to generate income and meet basic subsistence needs [9,12-14]. Based on fieldwork conducted in the village over the course of two years, water is the major emerging theme that unifies local vulnerabilities. Water devastates crops, destroys homes, and leaves residents fearing for their lives, while presenting a persistent disturbance for residents as they strive to provide for themselves and their households $[10,15]$. The chronic nature of worries over water characterizes local experiences 
with climate change and its aggravating effects on disasters. If we focus solely on largescale disasters, however, we miss the everyday, recurrent crises of water that residents persistently confront. Interviews with community members convey the endless struggles for clean water, on the one hand, and inundation of contaminated water, on the other, thus highlighting the contradictions of water logics and their intersection with global climate change that motivate this project.

\section{Literature Review}

Substantial progress has been made in sustainability studies to elaborate the interconnected nature of the biophysical and social world [16-19]. Of particular significance are those award-winning developments in coupled human and natural systems (CHANS) [1,2] which articulate the complex interactions (e.g., reciprocities, feedback loops, and telecoupling processes) [3] of nature and society that shape the sustainability of local and distant places. In an increasingly globalized world, refinements in CHANS analyses evidence a growing emphasis on the flows of material and energy across sending and receiving systems, and the spillover effects they produce. In other words, the effects of nation-tonation exchanges are not confined to the countries engaged in trade but spillover to impact, in principle, all other nations, whether by disrupting historic trade networks, initiating information exchanges, or introducing invasive species along the transportation routes used to complete transactions [3]. In fact, the framework has been the topic of past Special Issues in this very journal (Through the Lens of Telecoupling: New Perspectives for Global Sustainability. Sustainability 2019, 11). Most important to the present effort, CHANS analyses offer a framework for simultaneously considering socioeconomic and environmental interactions spanning systems from the local to the global level.

Since its inception in 2007, the CHANS framework has come to occupy a prominent place in scholarship across ecology, land use, natural resource management, social science, and sustainability science $[1-3,20]$. The framework is extremely versatile in its ability to integrate insights on human systems from social sciences with insights on natural systems from the biophysical sciences. It allows interdisciplinary researchers and research teams to holistically understand and evaluate the characteristics of human and natural systems through exploration of complex organizational, spatial, and temporal "couplings" [1,2]. Preliminary empirical elaboration of the CHANS framework emphasizes patterns and variations in the following characteristics across spatial, temporal, and organizational scales: reciprocal effects and feedback loops, nonlinearity and thresholds, surprises, legacy effects and time lags, resilience, and heterogeneity [1]. The succinct and applicable framework set the stage for subsequent empirical scholarship to thoroughly and comprehensively unpack the systemic complexity found within human-nature dynamics in discrete geographic locations [21-27].

Over the course of the last decade and a half, CHANS research has become both prominent and diffuse within human-environment scholarship. In 2007, the National Science Foundation established a CHANS research program titled "Dynamics of Coupled Natural and Human Systems" [1] to expand the scope, integration, and refinement of CHANS research projects. The "International Network of Research on Coupled Human and Natural Systems" (CHANS-Net) also emerged as a scholarly space to foster collaboration and community surrounding CHANS research but also to advance the theoretical and empirical potential of the CHANS framework. Notably, a recent article examining data collected from CHANS-Net to discern the most pressing and important research topics for future CHANS researchers ranks land use and agriculture of the utmost importance [28]. In this vein, this paper contributes to CHANS research generally through the production of new knowledge concerning the coupled human-nature dynamics of climate, land use, water, and population in an agricultural community in Eastern Uganda.

CHANS research has also been widely engaged in a variety of areas $[1,21,22,25,29,30]$. In particular, urban ecology has made significant use of CHANS as a way to explain the proximal dynamics of human and natural systems within urban spaces [20,31]. Urban- 
specific research has been important in the elaboration of CHANS heterogeneity across rural and urban spaces, with recent research revealing the tightly coupled human-natural mechanisms by which dynamic urban ecologies are changing and evolving at a rapid pace $[32,33]$. This urban-specific research is relevant here because the field location complicates traditional understandings of rural vs. urban, particularly with regard to expectations for low population density in rural environs.

Over time, the CHANS framework has evolved along a number of theoretical trajectories. CHANS emerged as a macro-level framework aimed at addressing complexity; accordingly, significant advances have been made in terms of modeling and simulating CHANS relations through the lens of systems and complexity theory [25,34-37]. In 2013, Liu et al. expanded upon the CHANS framework by introducing the umbrella concept of "telecoupling" [3]. Telecoupling emerged as a theoretical extension of CHANS in order to better explain the connections between human and natural systems across vast distances. In its original conception, the CHANS framework focused on explaining complex relations and processes within a singular geographic space, which was found to be inadequate in an increasingly connected, mobile, and globalizing world. Accordingly, telecoupling extends the CHANS approach through particular emphasis on the ways in which focal systems are connected to, or coupled with, distant social and environmental systems. The telecoupling framework comprises five component parts: coupled human and natural systems, agents, flows, causes, and effects [3]. Each component part speaks to a facet of the way that two, or more, CHANS relate to each other. The framework has been widely employed in empirical telecoupling studies emphasizing trade flows, information transfers, and species dispersal [38]. In its initial conceptualization, the telecoupling concept applied to a wide variety of concepts, such as migration, payments for ecosystem services, technology transfers, air circulation, water transfer, the transfer of pollutants and waste, and foreign direct investment, and these wide-ranging applications continue to gain traction within the literature (see, e.g., [39]). The present research engages the notion of socioeconomic and environmental interactions over distance in the evaluation of the localized water systems as experienced by citizens in the Bududa district.

A recent popular and promising extension of the CHANS approach is the metacoupling framework [40]. The metacoupling framework adds nuance to the CHANS and telecoupling frameworks while maintaining the clarity and applicability of these frameworks. Telecoupling acknowledges the socioeconomic and ecological interactions that happen between CHANS over distance. Metacoupling goes even further to establish a cumulative framework inclusive of socioeconomic and ecological interactions that occur far from (telecoupling), adjacent/ proximal to (pericoupling), and within (intracoupling) the focal CHANS [20,40].

CHANS and, by extension, the telecoupling and metacoupling frameworks provide interdisciplinary researchers and research teams with a highly flexible and widely applicable package of theories that allow for the holistic and comprehensive articulation of extremely complex socioeconomic and ecological interactions across spatio-temporal scales [1,3,40]. By understanding these complex interactions, CHANS researchers are well-positioned to contribute to global conversations about how to create nested and interactive sustainable systems [41]. We use this framework in our analysis of water dynamics in the Eastern Ugandan district of Bududa, the details of which we now present.

\section{Data and Methods}

\subsection{Data Collection Site}

Uganda is a landlocked nation in Eastern Africa. The Bududa District is located in the eastern region of the country, bordered by the Sironko District to the north, the Republic of Kenya to the east, the Manafwa District to the south, and the Mbale District to the west (see Figure 1). This district lies at the foot of one of the largest inactive volcanic mountains in the world: Mount Elgon. In fact, roughly half of the Bududa district overlaps with Mount Elgon National Park. The terrain throughout the district ranges from hilly to steep 
slopes unsuitable for cultivation and/or timber harvest [6,7]. The social and ecological implications of the district's entanglement with Mount Elgon are treated throughout.

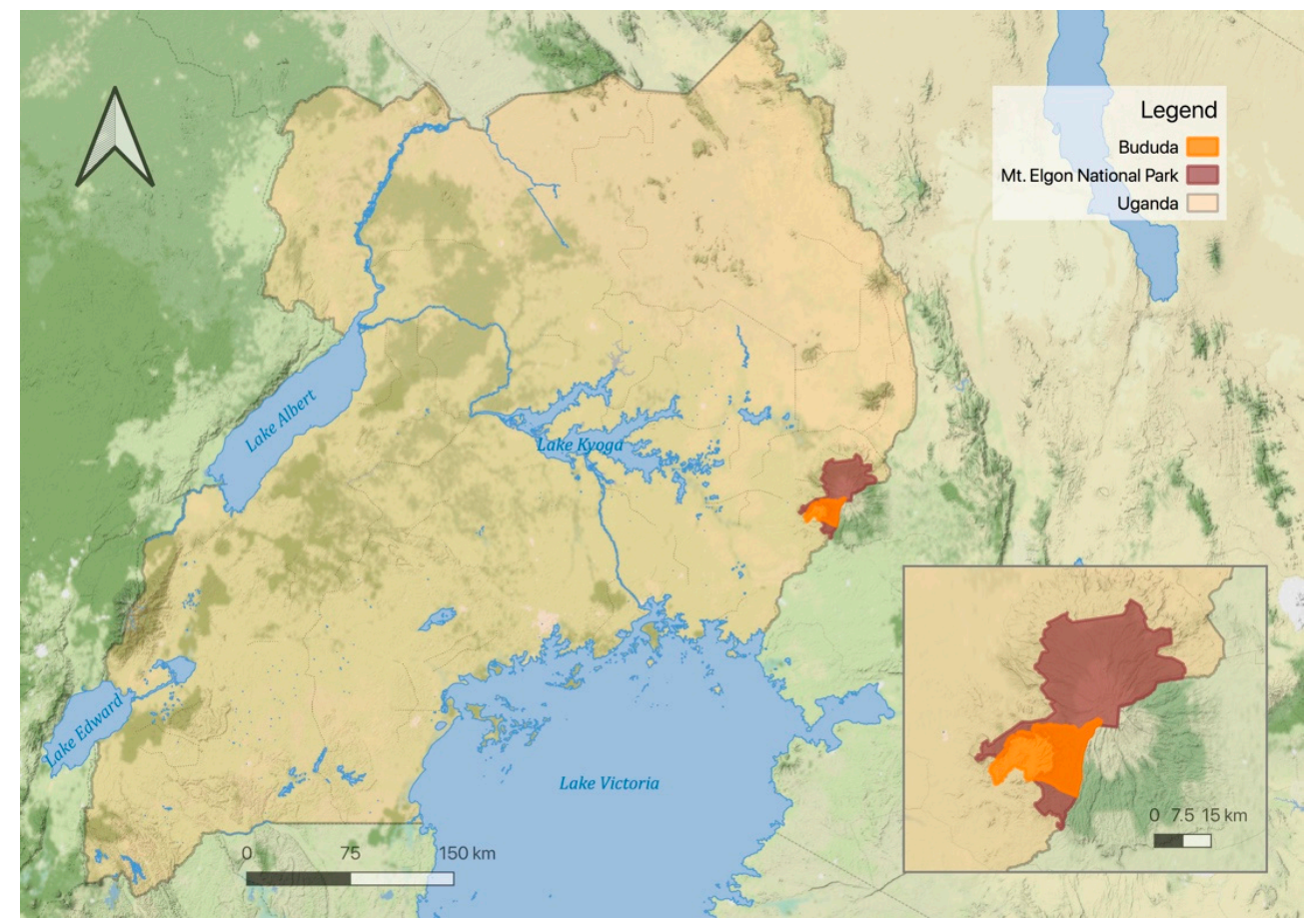

Figure 1. Map of Uganda. District explored shown in orange. Map produced by author using the following copyrighted material: (1) Map tiles by Stamen Design, under CC BY 3.0. Data by OpenStreetMap, under ODbL [42]. (2) Waterbodies in Uganda by World Resources Institute, under CC BY-NC 4.0. Data by Dartmouth Flood Observatory, under CC BY; National Imagery and Mapping Agency; National Forestry Authority [43-45]. (3) National and District Boundaries contributed by OCHA ROSEA licensed under CC BY-IGO. Data by Uganda Bureau of Statistics with support from WHO, under UBOS [46]. Geospatial data retrieved from: Humanitarian Data Exchange, World Resources Institute, and QGIS. Map produced in QGIS.

The population of the Bududa District is approximately 210,000, with a population growth rate of around 4.5 percent, which exceeds the national growth rate of 3 percent [47]. Similar to the overall national profile of Uganda, there is an extreme youth bulge in Bududa, with over half of the population (58.7\%) being less than 18 years of age [48]. Although Bududa is rural, it is unique in its relatively high population density of just over 950 people per square kilometer, a feature that is linked to an increase in both landslides and deforestation in the local area [6].

Economically, Bududa is one of the more impoverished districts in the nation of Uganda. While Uganda's GDP per capita currently rests at around USD 2200 [49], Bududa households earn around USD 100 per year on average. Households frequently rely on the commercial sale of coffee as a cash crop for cultivation [12], usually in combination with some forms of retail sales, transportation, livestock rearing, and limited tourism. The district is without formal water or sanitation systems and faces extremely limited supplies of electricity. In fact, most dwellings have no wiring for electricity and those that do mostly rely on inconsistent solar sources for their energy needs. Access to the district via roads is challenging - none are paved and they frequently suffer from flooding, gutting, hazardous shoulders, and overall poor conditions for driving and access.

Culturally, polygamy is a common practice in the district. Very traditional and conservative gender norms are widely adhered to locally, with women occupied by household tasks and men permitted to work across more formal economic opportunities such as those treated above. Given the reliance on subsistence farming, most households comprise 
extended family members spanning from the very young to very old generations all under one roof. With few exceptions, almost all members of the family are expected to contribute to household maintenance, though, depending on familial finances, most try to send their children to school for at least some introduction to formal education and exposure to speaking the English language [12].

Ecologically, Bududa is endowed with diverse natural resources including fertile soils from volcanic activity, a lush landscape, mountain-fed streams, and heavy rainfall. Well over 80 percent of the population rely on subsistence farming with small amounts of commercial sales to supplement their income. Area inhabitants heavily rely on these resources to produce timber and a variety of crops for subsistence and commercial sale [7,14]. However, mounting climate and population pressures are altering the short- and longterm availability/usability of these resources $[6,7,50]$. One study goes so far as to say that Bududa is the district most vulnerable to climate change in the entire country due to the flooding and landslide risk [9]. Thus, the district is in an extremely precarious position, with abundant natural resources that are posing an increasing risk to those reliant upon said resources.

\subsection{Data Collection and Analysis}

Data collected follow the case study methodology and qualitative structural fieldwork approach as outlined by Yin and Gellert and Shefner, respectively [8,51]. The qualitative case study methodology engages with a variety of qualitative modes of inquiry in order to comprehensively understand the case and answer the research questions [8]. The qualitative structural fieldwork approach challenges political economy and world systems researchers to connect structural change to everyday experience through situated fieldwork and macro-level social theoretical framing. This paper is informed by data collected from two visits to the field in November of 2018 and June of 2019, with both trips lasting approximately one month. Data collection methods included participant observation and semi-structured interviewing.

During 2018 and 2019 fieldwork, the research team engaged in participant observation in the Bududa region. Both team members maintained extensive field notes to record experiences as close as possible to their occurrence, temporally and spatially [52]. Research team members conducted observations in myriad settings including: community member homes, community spaces for gathering and commerce, sports fields, and within residential areas surrounding central gathering spaces. These observation periods contribute invaluable insight into the flows of daily life in Bududa and how residents are compelled to continuously engage with their ecological surroundings in intimate ways [53,54].

During fieldwork conducted in June 2019, the research team conducted 10 semistructured qualitative interviews with public officials and community members [55,56]. We supplement these data with insights gleaned from pilot data gathered in 2018, which spanned interactions with dozens of community members. The research team worked with a prominent local non-profit organization to recruit participants using convenience and snowball sampling. In order to ensure reliability and validity, efforts were made to secure a range of participants across occupations, classes, and community roles [55,57]. Participants included primary school educators/administrators, subsistence farmers, informally/inconsistently employed mothers, and agricultural officials. The research team achieved parity between the rate of participation in subsistence agriculture among the Bududa population (86\%) and the research sample (90\%) [9].

Formal interviews ranged from $13 \mathrm{~min}$ to $44 \mathrm{~min}$ in length, averaging $23 \mathrm{~min}$. Interviews took place in a variety of settings including government offices, outside of participant homes, and in a secluded area adjacent to the research team's base station/lodgings. Due to large family/household sizes and high population density, interior spaces often did not present adequate privacy for interview conduct. Despite increased visibility, outdoor settings actually presented greater opportunity for private conversation. Outdoor interviews 
also allowed participants to gesture to their surrounding environment and contextualize their responses within their immediate ecology and home space.

Interviews proceeded with the support of a local translator. Two participants preferred to use English in their responses, but the translator remained present throughout these interviews to ensure parity in participant and researcher understanding of particular words and phrases. An interview questionnaire guided the interviews; follow-up questions were asked as necessary and appropriate. Each interview was recorded. Upon return from the field, recorded interviews were transcribed by a research assistant and subsequently quality-checked by a member of the research team that participated in fieldwork as a measure of inter-rater reliability. The quality-checked transcriptions serve as the primary data analyzed for this article.

Interview transcripts were coded using line-by-line coding [58,59]. This technique is predicated upon the emergence of codes from within the data. Emergent codes are then grouped into categories, ultimately assembling coding trees arranged thematically. Line-by-line coding was completed in nVivo, a computer-assisted qualitative data analysis software (CAQDAS). The hierarchical arrangement (i.e., code forrest) and thematic coding process was completed manually and then transferred into nVivo to allow for further manipulation and analysis within the software.

Importantly, during our 2019 visit to the community to conduct fieldwork, a major rainstorm caused deadly landslides in the Bududa district $[15,60]$. The research team immediately halted interview data collection so as to limit interference with local emergency responses, disaster recovery, and cultural rites/rituals. In the immediate aftermath, the research team focused on understanding the ecological manifestations of the landslides, documenting the ways that it visibly altered the landscape and human settlement (i.e., flooded homes, destroyed crops, broken bridges), and internalizing the experience of living through such a tragic disaster event. Within days of the landslide, a portion of the affected population expressed renewed interest in continuing participation in the research in light of their recent experiences and landslide-related losses. The research team decided to resume interview data collection so as to preserve these stories and honor participant wishes. Subsequently collected data in the immediate wake of such disaster events offer unique insight into the acute manifestation of climate impacts on populations living in high-risk ecologies.

\section{Results}

The Bududa district is typified by recurrent and devastating landslides. Interviews show that these constant threats of landslides and other climate impacts weigh on Bududa residents, shaping their daily lives and their ability to plan for their households' futures. Participants expressed an acute awareness of their homeland's environmental precarity and recent climatic changes. Furthermore, respondents talked about the causal role of localized population growth and encroachment in triggering said changes. Importantly, observational and interview data suggest that the landslides characteristic of the area are not the major source of loss in the area's climate-related disasters. The research team finds that water is the major mechanism by which climate change impacts are felt in the community. Water impacts are spatially and temporally diffuse and are a far more chronic condition of the region relative to landslides. In fact, a major cause of landslides is water in the form of heavy rains that then over-saturate the steep slopes of Mt. Elgon [50,61]. The ongoing and spatially expansive nature of water impacts leads the research team to conclude that in Bududa, when various disasters strike, it is immediate community support that makes the greatest difference.

When asked about how recent landslides have affected their families, participants most frequently cited issues related to an excess of water. Some participants spoke of the landslides directly impacting their homes. Two participants recently experienced displacement as a result of shifting lands. One participant was displaced as a result of landslides that had happened in Bududa in the month prior to the 2019 fieldwork; the soils 
had not destroyed her home but were so close to the structure that the risk was imminent. One additional major rain event and her home would be crushed. She left with her children and permanently abandoned the home. Another participant had also been displaced as a result of landslide risk; his home was immediately beneath a portion of hillslope that had started "cracking" - a sign of impending landslide [62]. While profound and deeply consequential, these acute experiences of risk from land itself sliding were the minority among respondents. The overwhelming majority expressed that the most experientially impactful outcomes of landslides were in fact related to the ways that water moved and functioned before, during, and after the disaster events that were discursively typified as landslides.

Participants cited frequent flooding of their homes and crops, as well as significant limitations and complications that impede safe water access. Two participants shared that during any major rain event, which are the most immediate cause of the landslides, their homes flood-a particularly alarming event for these participants as their children sleep on the floor. These participants went on to mention the fear and worry that they now associate with rain, particularly heavy rains occurring overnight. Several other participants mentioned the destruction that waters cause to their crops, which are washed away as water rushes over newly transitioned crop lands. Crops are also washed away as water breaches river banks and swiftly moves across the extremely small-scale piecemeal subsistence plots typical of the area. The force of water literally washes away crops, but in other areas that are flatter and/or slightly further from the river, the flood waters then settle and create hypoxic conditions that kill the plants [63]. Given the pervasive reliance upon subsistence farming, crop loss poses grave threats to the short- and long-term food security of the immediate area.

Besides food access and shelter, water impacts also constrict the population's access to safe drinking water. In some cases, residents have access to "gravity water" or mountain water/rainwater that is stored in barrels on elevated platforms that then deliver water to homes and community spigots as needed. In many cases, residents are reliant upon river water or other sources of water (e.g., shallow wells) that become contaminated and unsafe during major rain events and landslides. Participants who are able amass as much safe water as possible prior to major rain events in anticipation of limited safe drinking water supplies. For those who cannot or do not prepare, they are reliant upon supplies from the government, disaster relief, and aid organizations or are compelled to scavenge for safe drinking water, which typically means leaving their immediate area and traveling lengthy distances.

Participants are intimately aware of these environmental impacts, both landslides and associated water impacts, as increasingly frequent, devastating, and therefore concerning. Landslides and excess water are outcomes of what participants recognize as a shifting rainy season that arrives earlier and more intensely than they are accustomed. The sudden onset of heavy downpours has myriad impacts on the socioecological life in the area. First, community members delay planting, which is speculated to result in yield loss due to diminished growing conditions and temporal windows from sowing seed to harvest season. Second, they create "soft" or "cracking" soils that are understood locally as highly susceptible to landslides [62]. Such unstable soils are of particular concern as severely sloped tracts typically thought unsuitable to cultivation are brought into production as a result of increasing population pressure in the region. Third, the rains cause significant soil erosion and depletion on sloped and relatively flat lands alike. Widespread erosion contributes to increases in local fertilizer use and, potentially, over-fertilization. This creates a domino effect wherein the fertilizers become an agricultural runoff that then further contaminates water supplies and initiates a fertilizer treadmill effect that begets greater and greater reliance on and use of synthetic inputs to maintain yields in light of declining soil health, increasing runoff, and high population pressure $[64,65]$.

While some of the environmental changes experienced by the residents of Bududa are local manifestations of global climate change (i.e., longer dry season, earlier and wetter 
rainy season), other environmental changes are much more closely linked to local population pressures and the uneven global distribution of poverty and subsequent environmental degradation. Alongside rain, participants cite the growing population as a main cause of the landslides. The population bulge in Bududa places significant pressure on local resources. Land already in cultivation is being stretched thin and soil exhaustion is mounting, which is also increasing the impetus for increased fertilizer use. Other protected lands in Mount Elgon National Park that are on the steep mountainsides in the area are being cleared, with timber and land used for housing or crop production despite the significant risk associated with attempting cultivation on such sloped soils and without any stabilizing measures [5,6]. Terracing, which is a strategy used around the globe for crop production on steep slopes, is uncommon in the region because of the extremely small plot sizes and the possibility of terracing to exacerbate landslides during heavy rains $[6,14]$. As a result, the root systems of established plant communities are essential in maintaining the soil structure in these locations [6]. The complexity of the local situation is compounded when considering the coupling of ecological constraints and land politics associated with encroachment into federally recognized protected areas (i.e., Mount Elgon National Park) [7,13]. Thus, climate impacts are deeply intertwined with regional population pressures and ultimately serve to exacerbate environmental degradation and social precarity/risk in the area.

A governmental relocation plan is in place and is expected to include many of the residents in the region, but thus far, participants convey that administration of the program has been sporadic, unpredictable, and often contradictory. One participant expressed their dissatisfaction with government support and the overall severity of the situation in saying, "the government only helps when you are dead." Participants widely expressed a hopeful willingness to leave their current homes, despite the uncertainty of where they might be going, so long as they and their families are safe. Findings show that residents of high-risk areas are increasingly willing to relocate irrespective of the cultural similarity of the potential relocation site, which was previously a major concern (see, e.g., [66,67]). This heightened sense of urgency can be understood as a byproduct of the increasing climate risk.

This kind of uninformed static existence, in limbo between a dangerous present and a hypothetically safe future, places pressure on families and limits their ability to make plans for what is to come or how best they might transition to a new life in a new environment. For now, the residents of Bududa are given little choice but to deal with their precarious socioecological positions using whatever piecemeal resources are at their disposal. When resources are not available, life grinds to a halt, at least temporarily. With each landslide, students miss school, bridges are destroyed, and transit halts. Flooding forces families to find shelter, food, water, and sleep, elsewhere. In their recovery, for residents of Bududa, this often means deep reliance on fellow community members for support.

\section{Discussion}

Interrogating the complexities of water, as localized systems, and their intersection with global climate change is the primary focus of this project. In doing so, the project engages the Sustainable Development Goal to establish safe water access as a basic human right by concretizing general and specific hurdles to its achievement in an era of global climate change [68]. This project, then, brings into focus a pivotal theme that unifies generations past and present, locations far and wide. As shown by the World Water Development Report [69], access to clean water is complicated by a host of social, economic, and environmental factors. Data gathered and presented here confirm these expectations and the project brings a level of nuance to bear on the broader conversation.

Through this analysis, it is apparent that disaster events, such as the landslides that present ever greater risk to the residents of Bududa, are not self-contained but are part of complex ecological and social systems [14]. Furthermore, it is clear that the residents of high-risk ecologies have causal understandings of their home environments that readily complicate imposed academic boundaries between human systems research and natural 
systems research [14]. Accordingly, the CHANS framework, and the telecoupling explanatory extension, are found to be critically important for analysis within this research. These frameworks allow us to see how global climate change, driven by emissions and consumption in industrialized nations, alters local hydrological systems and water flows. Telecoupling allows us to name agents and causes in far-off lands as part of the confluence of actors shaping water and its flows in Bududa [70].

In their initial formulations, the CHANS, telecoupling, and metacoupling frameworks are intended for large-scale quantitative exploration $[1,3,40]$, but given the recent emphasis on multidisciplinary research partnerships, it is imperative to include qualitative work as a means for ground-truthing posited quantitative findings, exploring the local validity of generalized claims, and providing meaningful nuance to these complex processes. Furthermore, qualitative work is particularly well-suited for the exploration of social processes and relations and is therefore methodologically likely to illuminate heretofore unconsidered agents and flows in telecoupled and metacoupled arrangements [54-56].

We suggest that CHANS research would benefit not only from methodological expansion but theoretical expansion or, rather, theoretical integration. In the case of the water CHANS in Bududa, some of the most salient "causes" of water impacts to area residents are socioeconomic in nature and grounded in global structures and legacies of inequality - the foremost in this case being colonialism. In order to integrate analysis of structural inequalities borne out in the field, we argue that the CHANS framework can and should be adapted to include an intersectionality lens [20,71]. We see CHANS and intersectionality analyses as complementary, but this is not yet reflected in the research. Future research should go further in blending these two important lines of research.

In this paper, we begin to analyze the changing relations between agents, causes, effects, and flows as related to the water CHANS in Bududa. We find that, by focusing on water, as opposed to the landslides themselves, we are able to understand the chronic environmental and socioeconomic vulnerabilities of the local population to a greater degree. As the everyday risks associated with the climate crisis grow, it is imperative that researchers focus not only on acute disasters but the ways in which disaster-like conditions extend over time as our biogeochemical cycling becomes increasingly unpredictable.

\section{Conclusions}

Collectively, this paper presents a number of conclusions applicable to the theoretical framework that we employ and companion methods of analysis. We list these below in bullet points:

- Our analysis highlights the chronic nature of worries over water, as opposed to acute;

- We also demonstrate the ubiquity of concerns with water, transcending across individuals to households and even institutions;

- We highlight the widespread beliefs that overpopulation and agricultural practices (e.g., intensive propagation and use of fertilizers) trigger landslides;

- Our results also point to the common desire among community member participants to be relocated to safer soils;

- Finally, we conclude that the CHANS framework would benefit from greater integration of intersectional and qualitative analyses, such as this.

Author Contributions: Conceptualization, L.M.; methodology, L.M. and D.C.W.; validation, D.C.W.; formal analysis, D.C.W.; data curation, L.M. and D.C.W.; writing-original draft preparation, L.M. and D.C.W.; writing-review and editing, L.M. and D.C.W.; supervision, L.M.; project administration, L.M.; funding acquisition, L.M. All authors have read and agreed to the published version of the manuscript.

Funding: This research was internally funded by the School of Liberal Arts, the Provost Office, and Newcomb Grant Institute at Tulane University. 
Institutional Review Board Statement: The study was conducted according to the guidelines of the Declaration of Helsinki and approved by the Institutional Review Board of Tulane University (study \#2019-607, approved 05/10/2019).

Informed Consent Statement: Informed consent was obtained from all subjects involved in the study.

Data Availability Statement: The data presented in this study are available on request from the corresponding author. The data are not publicly available due to concern for participant privacy.

Acknowledgments: The authors wish to thank Katherine Herman for her assistance in transcribing the qualitative data. We also sincerely thank the Zaale family and Pathways Development Initiative for their hospitality during our fieldwork.

Conflicts of Interest: The authors declare no conflict of interest.

\section{References}

1. Liu, J.; Dietz, T.; Carpenter, S.R.; Alberti, M.; Folke, C.; Moran, E.; Pell, A.N.; Deadman, P.; Kratz, T.; Lubchenco, J.; et al. Complexity of coupled human and natural systems. Science 2007, 317, 1513-1516. [CrossRef]

2. Liu, J.; Dietz, T.; Carpenter, S.R.; Folke, C.; Alberti, M.; Redman, C.L.; Schneider, S.H.; Ostrom, E.; Pell, A.N.; Lubchenco, J.; et al. Coupled human and natural systems. Ambio 2007, 36, 639-649. [CrossRef]

3. Liu, J.; Hull, V.; Batistella, M.; De Fries, R.; Dietz, T.; Fu, F.; Hertel, T.W.; Izaurralde, R.C.; Lambin, E.F.; Li, S.; et al. Framing sustainability in a telecoupled world. Ecol. Soc. 2013, 18, 18. [CrossRef]

4. Merz, L.; Yang, D.; Hull, V. A metacoupling framework for exploring transboundary watershed management. Sustainability 2020, 12, 1879. [CrossRef]

5. Bemigisha, J. Scoping Study for Strengthening Sustainable Environment and Natural Resources Management, Climate Change Adaptation and Mitigation in Uganda (Ss-Enrm Cca); UNDP Office: Kampala, Uganda, 2012.

6. Knapen, A.; Kitutu, M.; Poesen, J.; Breugelmans, W.; Deckers, J.; Muwanga, A. Landslides in a densely populated county at the footslopes of Mount Elgon (Uganda): Characteristics and causal factors. Geomorphology 2006, 73, 149-165. [CrossRef]

7. Mugagga, F.; Kakembo, V.; Buyinza, M. Land use changes on the slopes of Mount Elgon and the implications for the occurrence of landslides. Catena 2012, 90, 39-46. [CrossRef]

8. Yin, R.K. Case Study Research: Design and Methods, 4th ed.; Sage: Thousand Oaks, CA, USA, 2009; ISBN 9781412960991.

9. Alinda, F.; Ssekamatte, D.; Kisambira, E.; Kagoro, A. Advancing climate change adaptation in Ugandas agricultural programming for sustainable development: Key milestones and constraints. Afr. J. Environ. Sci. Technol. 2020, 14, 301-310.

10. Atuyambe, L.M.; Ediau, M.; Orach, C.G.; Musenero, M.; Bazeyo, W. Land slide disaster in eastern Uganda: Rapid assessment of water, sanitation and hygiene situation in Bulucheke camp, Bududa district. Environ. Health 2011, 10, 38. [CrossRef] [PubMed]

11. Masaba, S.; Mungai, D.N.; Isabirye, M.; Nsubuga, H. Implementation of landslide disaster risk reduction policy in Uganda. Int. J. Disaster Risk Reduct. 2017, 24, 326-331. [CrossRef]

12. Austin, K.F. Brewing unequal exchanges in coffee: A qualitative investigation into the consequences of the java trade in rural uganda. J. World Syst. Res. 2017, 23, 326-352. [CrossRef]

13. Cavanagh, C.J.; Benjaminsen, T.A. Guerrilla agriculture? A biopolitical guide to illicit cultivation within an IUCN Category II protected area. J. Peasant. Stud. 2015, 42, 725-745. [CrossRef]

14. Kitutu, M.G.; Muwanga, A.; Poesen, J.; Deckers, S. Farmer's perception on landslide occurrences in Bududa district, eastern Uganda. Afr. J. Agric. Res. 2011, 6, 7-18.

15. International Federation of Red Cross and Red Crescent Societies. Uganda: Floods and Landslides Emergency Plan of Action (EPoA); International Federation of Red Cross and Red Crescent Societies: Geneva, Switzerland, 2019.

16. Bettencourt, L.M.A.; Kaur, J. Evolution and structure of sustainability science. Proc. Natl. Acad. Sci. USA 2011, 108, 19540-19545. [CrossRef]

17. Kates, R.W. What kind of a science is sustainability science? Proc. Natl. Acad. Sci. USA 2011, 108, 19449-19450. [CrossRef]

18. ISSC; IDS; UNESCO. World Social Science Report 2016, Challenging Inequalities: Pathways to a Just World; UNESCO Publishing: Paris, France, 2016; ISBN 978-92-3-100164-2.

19. ISSC. UNESCO World Social Science Report 2013, Changing Global Environments; ISSC: Paris, France, 2013.

20. Liu, J.; Dietz, T.; Carpenter, S.R.; Taylor, W.W.; Alberti, M.; Deadman, P.; Redman, C.; Pell, A.; Folke, C.; Ouyang, Z.; et al. Coupled human and natural systems: The evolution and applications of an integrated framework. Ambio 2021, 33721224. [CrossRef]

21. Carter, N.H.; Viña, A.; Hull, V.; McConnell, W.J.; Axinn, W.; Ghimire, D.; Liu, J. Coupled human and natural systems approach to wildlife research and conservation. Ecol. Soc. 2014, 19, 19. [CrossRef]

22. Chen, J.; John, R.; Zhang, Y.; Shao, C.; Brown, D.G.; Batkhishig, O.; Amarjargal, A.; Ouyang, Z.; Dong, G.; Wang, D.; et al. Divergences of two coupled human and natural systems on the mongolian plateau. Bioscience 2015, 65, 559-570. [CrossRef]

23. Lassoie, J.P.; Sherman, R.E. Promoting a coupled human and natural systems approach to addressing conservation in complex mountainous landscapes of Central Asia. Front. Earth Sci. China 2010, 4, 67-82. [CrossRef] 
24. Schäfer, H.; Miyaguchi, T.; Yoshizumi, M.; Tung, N. Complexity of the socio-ecological dynamics in hong ha commune in the vietnamese highland-A review through the coupled human and natural systems framework. Sustainability 2020, $12,6232$. [CrossRef]

25. Spies, T.A.; White, E.M.; Kline, J.D.; Fischer, A.P.; Ager, A.; Bailey, J.; Bolte, J.; Koch, J.; Platt, E.; Olsen, C.S.; et al. Examining fire-prone forest landscapes as coupled human and natural systems. Ecol. Soc. 2014, 19, 19. [CrossRef]

26. Turman-Bryant, N.; Nagel, C.; Stover, L.; Muragijimana, C.; Thomas, E.A. Improved drought resilience through continuous water service monitoring and specialized institutions-A longitudinal analysis of water service delivery across motorized boreholes in northern kenya. Sustainability 2019, 11, 3046. [CrossRef]

27. Wandersee, S.M.; An, L.; Lopez-Carr, D.; Yang, Y. Perception and decisions in modeling coupled human and natural systems: A case study from Fanjingshan National Nature Reserve, China. Ecol. Model. 2012, 229, 37-49. [CrossRef]

28. Kramer, D.; Hartter, J.; Boag, A.; Jain, M.; Stevens, K.; Nicholas, K.; McConnell, W.; Liu, J. Top 40 questions in coupled human and natural systems (CHANS) research. Ecol. Soc. 2017, 22, 22. [CrossRef]

29. Ferraro, P.J.; Sanchirico, J.N.; Smith, M.D. Causal inference in coupled human and natural systems. Proc. Natl. Acad. Sci. USA 2019, 116, 5311-5318. [CrossRef] [PubMed]

30. Morzillo, A.T.; De Beurs, K.M.; Martin-Mikle, C.J. A conceptual framework to evaluate human-wildlife interactions within coupled human and natural systems. Ecol. Soc. 2014, 19, 19. [CrossRef]

31. Alberti, M. Advances in Urban Ecology: Integrating Humans and Ecological Processes in Urban Ecosystems; Springer: New York, NY, USA, 2008

32. Alberti, M.; Palkovacs, E.P.; Roches, S.D.; De Meester, L.; Brans, K.I.; Govaert, L.; Grimm, N.B.; Harris, N.C.; Hendry, A.P.; Schell, C.J.; et al. The complexity of urban eco-evolutionary dynamics. Bioscience 2020, 70, 772-793. [CrossRef]

33. Roches, S.D.; Brans, K.I.; Lambert, M.R.; Rivkin, L.R.; Savage, A.M.; Schell, C.J.; Correa, C.; De Meester, L.; Diamond, S.E.; Grimm, N.B.; et al. Socio-Eco-Evolutionary dynamics in cities. Evol. Appl. 2021, 14, 248-267. [CrossRef] [PubMed]

34. An, L. Modeling human decisions in coupled human and natural systems: Review of agent-based models. Ecol. Model. 2012, 229, 25-36. [CrossRef]

35. Boumans, R.; Roman, J.; Altman, I.; Kaufman, L. The Multiscale Integrated Model of Ecosystem Services (MIMES): Simulating the interactions of coupled human and natural systems. Ecosyst. Serv. 2015, 12, 30-41. [CrossRef]

36. Liu, X.; Liang, X.; Li, X.; Xu, X.; Ou, J.; Chen, Y.; Li, S.; Wang, S.; Pei, F. A future land use simulation model (FLUS) for simulating multiple land use scenarios by coupling human and natural effects. Landsc. Urban Plan. 2017, 168, 94-116. [CrossRef]

37. Liu, H.; Fang, C.; Fang, K. Coupled human and natural cube: A novel framework for analyzing the multiple interactions between humans and nature. J. Geogr. Sci. 2020, 30, 355-377. [CrossRef]

38. Kapsar, K.E.; Hovis, C.L.; Da Silva, R.F.B.; Buchholtz, E.K.; Carlson, A.K.; Dou, Y.; Du, Y.; Furumo, P.R.; Li, Y.; Torres, A.; et al. Telecoupling research: The first five years. Sustainability 2019, 11, 1033. [CrossRef]

39. McKinney, L.A. Foreign direct investment, development, and overshoot. Soc. Sci. Res. 2014, 47, 121-133. [CrossRef] [PubMed]

40. Liu, J. Integration across a metacoupled world. Ecol. Soc. 2017, 22, 22. [CrossRef]

41. Hovis, C.; Dou, Y.; Herzberger, A.; Liu, J. Through the lens of telecoupling and metacoupling: New perspectives for global sustainability. Sustainability 2021, 13, 2953. [CrossRef]

42. Stamen Design. Terrain Background Map; Stamen Design: San Francisco, CA, USA, 2020. Available online: http://maps.stamen. com/\#watercolor/12/37.7706/-122.3782 (accessed on 7 May 2021).

43. Brakenridge, G.R.; Anderson, E.; Caquarad, S. Global Active Archive of Large Flood Events; Data Selected for Lake Victoria; Dartmouth Flood Observatory: Hanover, NH, USA, 2006.

44. National Imagery and Mapping Agency. Vector Map Level 0 (Digital Chart of the World); National Imagery and Mapping Agency (NIMA): Fairfax, VA, USA, 1997.

45. National Forest Authority. National Forest Authority Land Cover GIS Database; Government of Uganda, NFA: Kampala, Uganda, 1996.

46. Uganda Bureau of Statistics. Uganda-Subnational Administrative Boundaries; Uganda Bureau of Statistics: Kampala, Uganda, 2020.

47. Uganda Bureau of Statistics. National Population and Housing Census 2014; Uganda Bureau of Statistics: Kampala, Uganda, 2016.

48. Uganda Bureau of Statistics. The National Population and Housing Census 2014- Area Specific Profile Series; Uganda Bureau of Statistics: Kampala, Uganda, 2017. Available online: https://www.ubos.org/wp-content/uploads/publications/2014CensusProfiles/ BUDUDA.pdf (accessed on 21 July 2021).

49. The World Bank. World Development Indicators; The World Bank Group: Washington, DC, USA, 2021.

50. Ngecu, W.M.; Nyamai, C.M.; Erima, G. The extent and significance of mass-movements in Eastern Africa: Case studies of some major landslides in Uganda and Kenya. Environ. Earth Sci. 2004, 46, 1123-1133. [CrossRef]

51. Gellert, P.K.; Shefner, J. People, place, and time: How structural fieldwork helps world-systems analysis. J. World Syst. Res. 2009, 15, 193-218. [CrossRef]

52. Joffe, C.; Emerson, R.M.; Fretz, R.I.; Shaw, L.L. Writing ethnographic fieldnotes. Contemp. Sociol. A J. Rev. 1996, 25, 705. [CrossRef]

53. Jerolmack, C.; Khan, S. Talk is cheap: Ethnography and the attitudinal fallacy. Sociol. Methods Res. 2014, 43, 178-209. [CrossRef]

54. Lamont, M.; Swidler, A. Methodological pluralism and the possibilities and limits of interviewing. Qual. Sociol. 2014, 37, 153-171. [CrossRef] 
55. Adler, P.A.; Adler, P.; Weiss, R.S. Learning from strangers: The art and method of qualitative interview studies. Contemp. Sociol. A J. Rev. 1995, 24, 420. [CrossRef]

56. Weiss, R.S. In their own words: Making the most of qualitative interviews. Context 2004, 3, 44-51. [CrossRef]

57. Small, M.L. 'How many cases do I need?': On science and the logic of case selection in field-based research. Ethnography 2009, 10, 5-38. [CrossRef]

58. Charmaz, K. Grounded Theory. In Qualitative Psychology: A Practical Guide to Research Methods; Smith, J.A., Ed.; Sage Publications, Inc: Thousand Oaks, CA, USA, 2008; pp. 81-110. ISBN 0-7619-7230-7.

59. Saldaña, J. The Coding Manual for Qualitative Researchers, 2nd ed.; Sage: Thousand Oaks, CA, USA, 2013; ISBN 1-4739-4359-0.

60. FloodList. FloodList Uganda—5 Dead, Dozens Missing After Landslides in Eastern Region; FloodList: Berlin, Germany, 2019.

61. Highland, L.M.; Bobrowsky, P. The Landslide Handbook-A Guide to Understanding Landslides; US Geological Survey Circular 1325: Reston, VA, USA, 2008.

62. Makabayi, B.; Musinguzi, M.; Otukei, J.R. Estimation of ground deformation in landslide prone areas using GPS: A case study of Bududa, Uganda. Int. J. Geosci. 2021, 12, 213-232. [CrossRef]

63. Jackson, M.B.; Colmer, T.D. Response and adaptation by plants to flooding stress. Ann. Bot. 2005, 96, 501-505. [CrossRef] [PubMed]

64. Carolan, M. The Sociology of Food and Agriculture; Routledge: New York, NY, USA, 2016; ISBN 978-1-317-36861-8.

65. Weis, T. The Global Food Economy: The Battle for the Future of Farming; Zed Books: London, UK; New York, NY, USA, 2007.

66. Neema, S.; Bua, G.M.; Tuhebwe, D.; Ssentongo, J.; Tumuhamye, N.; Mayega, R.W.; Fishkin, J.; Atuyambe, L.M.; Bazeyo, W. Community perspective on policy options for resettlement management: A case study of risk reduction in Bududa, eastern Uganda. PLoS Curr. 2018, 10. [CrossRef]

67. Kick, E.L.; Fraser, J.C.; Fulkerson, G.M.; McKinney, L.A.; de Vries, D. Repetitive flood victims and acceptance of FEMA mitigation offers: An analysis with community-system policy implications. Disasters 2011, 35, 510-539. [CrossRef]

68. United Nations. Division for Sustainable Development Goals. In UN Sustainable Development Goals; United Nations: Department of Economic and Social Affairs: New York, NY, USA, 2018. Available online: https:/ /sdgs.un.org/goals (accessed on 21 July 2021).

69. WWAP (UNESCO World Water Assessment Programme). The United Nations World Water Development Report 2019: Leaving No One Behind; UNESCO: Paris, France, 2019. Available online: https:/ / unesdoc.unesco.org/ark:/48223/pf0000367306 (accessed on 21 July 2021).

70. Carlson, A.K.; Zaehringer, J.G.; Garrett, R.D.; Silva, R.F.B.; Furumo, P.R.; Rey, A.N.R.; Torres, A.; Chung, M.G.; Li, Y.; Liu, J. Toward rigorous telecoupling causal attribution: A systematic review and typology. Sustainability 2018, 10, 4426. [CrossRef]

71. Crenshaw, K. Demarginalizing the intersection of race and sex: A black feminist critique of antidiscrimination doctrine, Feminist theory and antiracist politics. Univ. Chic. Leg. Forum 1989, 139, 8. 